Portland State University

PDXScholar

\title{
Adoption and Child Trafficking: Structural Violence in the International Adoption System
}

Vanessa Virgiel

Portland State University

Follow this and additional works at: https://pdxscholar.library.pdx.edu/honorstheses

\section{Let us know how access to this document benefits you.}

\section{Recommended Citation}

Virgiel, Vanessa, "Adoption and Child Trafficking: Structural Violence in the International Adoption System" (2014). University Honors Theses. Paper 114.

https://doi.org/10.15760/honors.116

This Thesis is brought to you for free and open access. It has been accepted for inclusion in University Honors Theses by an authorized administrator of PDXScholar. Please contact us if we can make this document more accessible: pdxscholar@pdx.edu. 
Adoption and Child Trafficking: Structural Violence in the International Adoption System

\author{
by \\ Vanessa Virgiel
}

An undergraduate honors thesis submitted in partial fulfillment of the requirements for the degree of

Bachelor of Arts

in

University Honors

and

Applied Linguistics, Arts \& Letters, and Liberal Studies

Thesis Adviser

Dr. Kimberley Brown

Portland State University

2014 
Adoption and Child Trafficking: Structural Violence in the International Adoption System (C) 2014 Vanessa Virgiel 


\section{ACKNOWLEDGMENTS}

Firstly, I must thank my thesis adviser, Dr. Kim Brown of the Applied Linguistics department. She has been a mentor to me ever since I enrolled at Portland State, and her unceasing guidance and support since then has helped shaped the trajectory of my academic career in ways I never anticipated when I first returned to school.

I owe thanks to Dr. Ann Marie Fallon and Nora Quiros of the Honors College; their flexibility and patience through this process allowed me to change course and pursue a topic of research I was passionate about.

Thank you to Dr. Steve Thorne of the World Literature and Languages department, whose enthusiastic support for my idea of studying power dynamics in adoption boosted my confidence in pursuing it as a thesis topic.

Thank you to my parents, Thomas and Eva Virgiel for their encouragement. My mother's kindly admonishment to me after many weeks of research to "Stop reading about it, and start writing it" turned out to be some of the soundest advice I received during this thesis process.

Thank you to my two dear friends and Applied Linguistics cohorts, Renee Rogers and Ayu Komiyama. Thank you for listening to me kvetch, for encouraging me to keep going, and for keeping me company during the long bursts of writing. 


\section{KEY TERMS}

Adoptee - A person who has been adopted. Legally this can take on different meanings depending on the context (e.g., when an adult who is severely mentally impaired is adopted by another adult relative), but for the purposes of this study refers exclusively to minors (defined as those under 18) that are adopted.

Birth family - In practice this can refer to the birth parents, one birth parent (e.g., mother or father) (Herman, 2012, "Birth Parents"), or an adoptee's extended natal family.

Destination country (aka Receiving country or receiving nation) - The country to which an (international) adoptee immigrates (e.g., if a Cambodian adoptee migrates to the United States to join their adoptive American family, then the United States is the destination country). For the purposes of this study, the destination country is restricted to the United States.

Independent adoption - An adoption, either domestic or international, that is done via the intermediary of an attorney instead of an adoption agency.

International adoption - Those persons who migrate from one nation to join a family residing in another nation. Other terms include intercountry adoption and transnational adoption, which are used interchangeably. 
Intracountry adoption (aka domestic adoption) - An adoption conducted within a single nation state (e.g., an American citizen adopting an American child, or a Chinese citizen adopting a Chinese child.)

Origin country (aka Sending country or sending nation) - The country from which an (international) adoptee emigrates (e.g., an adoptee from Ethiopia is adopted by a family in the United States, then Ethiopia is the origin country.)

Structural violence - A violence embedded within a social or institutional structure which causes harm to a group of persons. 


\begin{abstract}
In the United States there exists as part of the institution of international adoption a hegemony of "saving" orphans from developing or economically devastated nations. This hegemony is a factor contributing to an adoption "market" in orphans, leading to incidences of the trafficking of children as part of the intercountry adoption system. This study's purposes are thus twofold. First it is a preliminary attempt within the academic realm to determine the emergence of this hegemony by delineating the US history of intercountry adoption from its origins in the mid-1940s as a response to humanitarian crises, to its current status as a market commodifying children from developing and economically devastated countries. Secondly it is to assess the institution of international adoption as it relates to the concept of structural violence via case studies of child trafficking. The conclusion of this study suggests that until intercountry adoption is recognized as a form of structural violence against children and families in developing nations to serve the current hegemony in the United States of adoptive saviordom, instances of intercountry child trafficking will continue to persist.
\end{abstract}




\section{TABLE OF CONTENTS}

Copyright Notice..................................................... p.

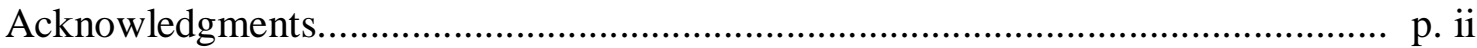

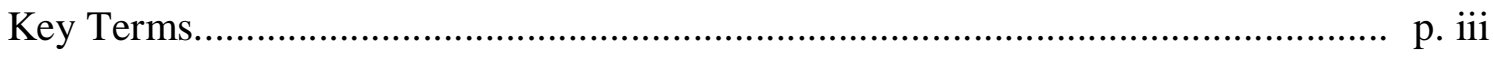



Table of Contents.................................................................................

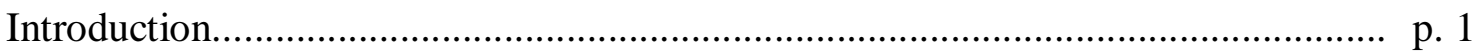

Part I - A Diachronic Study of International Adoption to the United States: The Emergence of the Adoption Savior Hegemony........................................... p. 8

Part II - Theoretical Underpinnings: Galtung's Typology of Structural Violence..... p. 15

Part III - Structural Violence in International Adoption: Case Studies of Child Trafficking..................................................................................... p. 18



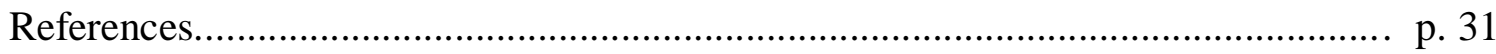




\section{INTRODUCTION}

\section{Personal Reflection: How This Topic Was Chosen}

Earlier this year, I was doing my usual routine online of perusing my favorite social media sites. I found that among my favorite social justice bloggers were a small number of people who also wrote about international adoption issues. These bloggers (Heit, n.d.a; Goudreau, 2014) were adoptees who wrote with a critical eye to the system of international adoption. Among the issues they shared from their experience and research were such topics as cultural loss and acculturation, their frustration with their adoption agency records, and their damning condemnations of the international adoption system which they maintained had commodified them and other adoptees.

Not being an adoptee myself, or even having anyone in my immediate family who is either an adoptee or an adoptive parent, I felt nonetheless felt compelled that I should read these web log posts, if only in the capacity as a legitimate peripheral participant. I was not disbelieving of what I read, but rather astonished; it had, quite simply, never occurred to me that placement by adoption could ever be motivated by profit (as these bloggers alleged was the case with Holt International, the agency who placed them), or otherwise corrupt. I had accepted without question the common discourse within my culture - that of the white, middle class American - that adoption was a wonderful institution which brought together parent-less children with families. Was this in fact a problematic hegemony held by my cultural group that I had not heretofore not recognized? After reading some of these web log posts, I became increasingly inquisitive as to the nature of the international adoption structure, and as I read more 
I began to make parallels between it and the concept of structural violence, which I had become acquainted with somewhat due to my burgeoning interest in critical theory.

Initially in my research I was focused on the social institution of adoption agencies; the early case studies of child trafficking for adoption - that is, those children from other nations who were not "true" orphans but were illegitimately placed for adoption to the United States still - appeared to be associated with unscrupulous adoption agencies motivated by profit. To that end, I did the preliminary work of a critical multimodal discourse analysis of a select number of adoption agency websites (Virgiel, 2014), where I determined that there was discursive evidence of a marketing-speak related to the orphans these adoption agencies were "advertising", suggesting the possibility of a discourse promoting commodification. As I went further, however, it soon became apparent to me that in order to unpack, as it were, how child trafficking in international adoption could have become embedded into its structure, it would be necessary to take a retrospective look at adoption in the United States, and a clarification of what exactly was inferred in correlating the idea of structural violence with adoption. This study is the resulting effort of my inquiry into these ideas.

\section{Introduction to the Topic}

International adoption has been an established practice in the United States for the past several decades. From the World War II era, when war orphans from Europe were permitted to migrate to the United States, to the present day, international adoption has formed a part of American social life. The ideology (Van Dijk, 1998) surrounding adoption-the unification of a family-less child from a developing nation with that of a loving, prosperous American family- 
has long been promoted in an idyllic manner, with members of the socially dominant white middle-to-upper-class having been on occasion exhorted to "save" a child from a developing nation, and thus enrich the love in their own family. It is not uncommon to find a news piece speaking of a so-called global orphan crisis of children awaiting families, as this excerpt from the Christian Post (2010) illustrates:

The nations' largest adoption agency announced on Monday that it had the highest-ever increase in adoption placements for a halfyear period in 2010 .

..We at Bethany [Christian Services] feel like one of the major problems is the global orphan crisis. There are 163 million orphans worldwide," said Mark Andreas, vice president of marketing and communications at Bethany Christian Services to The Christian Post on Tuesday. "That is just a staggering number.” (Vu, 2010)

Correspondingly, there is also ample news and "infotainment" materials promoting the "gift" of adoption, with adoptees and adoptive parents alike sharing praise for the adoption mechanism that allowed them to become family (Winfrey, n.d.), as well as advocacy from non-parties to adoption (Kennedy, 1994). Indeed, there appears to be a widely shared discourse among the white, middle-to-upper class Americans that make up the majority of adoptive parents (Lovelock, 2000; Herman, 2012e) that adoption is an altruistic structure which is socially beneficial to all parties (Graff, 2008), whitewashing the loss of birth families in placing their child(ren) for adoption (Stanley, 2013).

Yet in a seeming paradox, there is ample documentation demystifying international 
adoption and revealing evidence of such forms of violence and corruption as child trafficking. These texts, often either critiquing in order to reform (or altogether damning) international adoption, have come from a wide variety of mediums: news outlets (Filipovic, 2013; Graff, 2008; Greenblatt, 2011; Porter, 1993; Voigt, 2013; Voigt \& Brown, 2013), social media sites such as web log posts, where adult adoptees share their experiences (Heit, n.d.a; Goudreau, 2014; Evans, 2014; Stanley, 2013), international law (Dillon, 2003; Smolin, 2005; Blair, 2005), and other fields. This extract from Foreign Policy provides a sampling of a stance that appears to be widely shared among those aforementioned sources criticizing the structural integrity of international adoption:

Westerners have been sold the myth of a world orphan crisis. We are told that millions of children are waiting for their 'forever families' to rescue them from lives of abandonment and abuse. But many of the infants and toddlers being adopted by Western parents today are not orphans at all. Yes, hundreds of thousands of children around the world do need loving homes. But more often than not, the neediest children are sick, disabled, traumatized, or older than 5. They are not the healthy babies that... most Westerners hope to adopt. There are simply not enough healthy, adoptable infants to meet Western demand - and there's too much Western money in search of children. As a result, many international adoption agencies work not to find homes for needy children but to find children for Western homes. (Graff, 2008) This apparently harsh assessment of the international adoption institution paints a stark 
picture. If founded, these criticisms lead to a number of questions: if there isn't an "orphan crisis", why is it considered acceptable within majority white-culture social discourse to speak of needy children the world over who need loving homes? (Or, to phrase it plainly, why do we hear about so many orphans who need homes, if there is an apparent lack of them?) From where did the discourse and practice of American parents providing homes for poor children from developing or otherwise economically devastated nations emerge? To what extent is structural violence embedded in the international adoption system? Is it a fair assessment to state that there exists a hegemony towards children in developing nations, such that they are "in need of" Western homes?

This study is the result of my foray into the multi-disciplinary field of adoption studies, and to determine a) from where the existence of the hegemony of "adoption saviordom" originated, and b) if the term "structural violence" is an appropriate categorization of the international adoption system, in consideration of the documented instances of child trafficking (Smolin, 2005, Dillon, 2003; Rafferty, 2010; Kapstein, 2003; Graff, 2008; Leifsen, 2008; Wittern, 2003; Mullings, et. al, 2010; Getachew, 2012). In facilitation of these research goals, this study is divided into three major components. The first is a diachronic analysis of international adoption in the United States, in order to determine from where the "adoption saviordom" ideology emerged, subsequently leading to a power imbalance (and thus structural violence) in the international adoption system. The second is an exploration of the term structural violence, borrowed from the field of conflict resolution and peace studies, and how it shall be used as the theoretical underpinning examining the synchronic state of international adoption at present. The third component consists of said synchronic analysis by examining two case studies of child trafficking for international adoption to the United States, utilizing the 
established typology of structural violence.

In conducting this study, I have relied upon varying texts related to the academic disciplinary fields of adoption and the study of structural violence, rather than engaging in empirical research. Thus, this study's function is an extended literature review that synthesizes some of the findings of these divergent fields. International adoption, despite having long been an established social practice in the United States, has never been subject to formal studies regarding a possible embedding of structural violence in its system, though as previously mentioned there is ample literature documenting both instances of the commodification of children for adoption to the United States and other nations, and the harmful effects on birth families and the children's communities of heritage (Heit, n.d.a; Smolin, 2005; Roberts, 2013; Evans, 2014; Hermann \& Kasper, 1992). Additionally, as of this writing, no academic study of an inherent ideology (Van Dijk, 1998) behind international adoption was locatable, though here again, a plethora of documentation from the history of adoption, social media, and news sites amply demonstrate its existence. This study, then, is an attempt to demonstrate the presence of structural violence in the international adoption system, and a preliminary endeavor in identifying a hegemony of adoption "saviordom". It is my hope that doing so will bring to fruition the beginnings of an interest in researching this topic in the academic realm, in the hopes of inspiring a larger body of literature to which adoption reformers and other advocates could call upon in the near future.

However, a caveat is in order: it is necessary to clarify the parameters of this study by clarifying what is not included herein: the field of adoption studies is wide-ranging, and it should be self-evident that many facets—albeit important ones—have necessarily been omitted. One such omission is the study of adoption to other receiving nations besides than the United States. 
While the U.S. and other wealthy, Western countries such as Canada, Australia, New Zealand, and the Western and Central European nations share a history of intercountry adoption, their respective constructions of adoption as a social practice have varied widely (Lovelock, 2000; Hübinette, 2003). Even such nations that are politically allied and in geographical proximity to each other — such as the United States and Canada — have divergent histories of international adoption. Thus, what can be said for one receiving nation cannot necessarily be stated with equal confidence for the other, and vice versa. Therefore, this study exclusively focuses on the United States as the receiving nation.

Another conscious omission includes an analysis of the motivations and effects of adoption at the individual level. Though "international adoption and overseas adoptees complicate issues of ethnic identity and national belonging" (Hübinette, 2005), such a study is outside the scope of this thesis. It is my contention that such micro-level analyses, though essential to understanding the construct of adoption, is best served by qualitative research such as ethnographies, as well as (and perhaps more importantly) by the first person narratives of adoptive parents and adoptees themselves. This study is an attempt at a macro-level analysis, of a "savior" hegemony and structural violence embedded within the institutional, social level of international adoption. 


\section{PART I - A DIACHRONIC STUDY OF INTERNATIONAL ADOPTION TO THE UNITED STATES}

The Emergence of the Adoption Savior Hegemony

International adoption, with the United States acting as a receiving country, began in the 1940s following the end of World War II (Lovelock, 2000; Kapstein, 2003). Promoted as a humanitarian gesture, orphans and other displaced minors were allowed to migrate permanently to the United States under the Displaced Persons Act of 1948 (Lovelock 2000; Kapstein, 2003). In following wars with American military involvement, such as the Korean War, Americans were encouraged to adopt children from these war-torn territories (Lovelock, 2000). This began what has been termed the first wave of international adoption in the United States, wherein the premise was in "finding families for children" (Lovelock, 2000). There began here a concerted effort among pro-adoption activists to promote the idea of international adoption hand in hand with transracial adoption, as most adoptive parents in formalized adoption procedures were white, middle-to-upper class (Lovelock, 2000; Herman, 2012e), and the available pool of adoptees were of Asian or bi-racial origin. Such efforts were often coupled in tandem with efforts to promote domestic adoption of black children as well. An example of this can be demonstrated through one of the earlier adoption agencies to advance both international and domestic, interracial adoptions: Welcome House Adoption Program, established in 1949 by author and social activist Pearl S. Buck. Her endeavor to "find adoptive families for bi-racial children that were considered 'unadoptable' because of their ethnic [sic] status" ("Welcome house: A historical perspective", n.d.), in combination with the efforts of her activist peers, 
helped to generate a great deal of attention to international adoption. Pearl Buck was an adoptive mother of multi-racial children herself, and the enormous popularity of her books ${ }^{1}$, primarily centered on Asia, had propelled her as a popular activist on issues relating to Asia, race, and women's issues. She was thus one of the primary movers in the initiative of encouraging "mixed-race" adoptions in the US, emphasizing the benefits of adopting from Asia and domestically within the US. As part of her championing, she wrote a highly publicized piece "I Am the Better Woman for Having My Two Black Children" (1972), an excerpt of which is reproduced below:

My husband and I thought our family of five adopted children was complete when she first came to us. Her birth mother was a girl in a small town in Germany. Her father was an American soldier who was killed. He was black. The German mother said his black child was despised in her town and had no future there. She begged his university president in Washington to find the father's family.

I was a trustee of the university. We tried to find the family, but they had disappeared without trace. What then should we do with the child? From experience we knew that the little black children from Germany had difficulty adjusting to black mothers. The president looked at me. "Would you..." "Of course I will," I said. "We'd love to have another

1 Among her works is the novel Hidden Flower, whose plotline concludes with the bi-racial infant son of a Japanese mother and a white American military father being adopted by a white German-American professional woman. 
child."

I lived in a white community. But I knew it would make no difference to me or to my husband that this child was black, and since it made no difference to us, it should make no difference to our white children. If it did, I wanted to know it and see to it that attitudes were changed. If there were wrong attitudes in the school or community, I would see to that, too. If the basic love was in the home, the child would be fortified enough to be a survivor..."

(Buck, 1972)

However, this promulgation of interracial adoption was not a sentiment that was wholeheartedly endorsed by all Americans involved in adoption and issues of race. Other adoption activists preferred the established course of adoption "matching" (Herman, 2012a), via race and ethnicity, as it was considered to be in the best interests of the child to be raised in the cultural heritage into which they had been born. One of the more persuasive arguments, which had a large effect on domestic interracial adoptions came in 1972 statement from the National Association of Black Social Workers, an excerpt of which is reproduced below:

The National Association of Black Social Workers has taken a vehement stand against the placement of black children in white homes for any reason. We affirm the inviolable position of black children in black families where they belong physically, psychologically and culturally in order that they receive the total sense of themselves and develop a sound projection of their future.

Ethnicity is a way of life in these United States, and the 
world at large; a viable, sensitive, meaningful and legitimate societal construct. This is no less true nor legitimate for black people than for other ethnic groups....

The socialization process for every child begins at birth and includes his cultural heritage as an important segment of the process. In our society, the developmental needs of Black children are significantly different from those of white children. Black children are taught, from an early age, highly sophisticated coping techniques to deal with racist practices perpetrated by individuals and institutions. These coping techniques become successfully integrated into ego functions and can be incorporated only through the process of developing positive identification with significant black others. Only a black family can transmit the emotional and sensitive subtleties of perception and reaction essential for a black child's survival in a racist society. Our society is distinctly black or white and characterized by white racism at every level. We repudiate the fallacious and fantasied reasoning of some that whites adopting black children will alter that basic character.

We fully recognize the phenomenon of transracial adoption as an expedient for white folk, not as an altruistic humane concern for black children. The supply of white children for adoption has all but vanished and adoption agencies, having always catered to middle class whites developed an answer to their desire for 
parenthood by motivating them to consider black children. This has brought about a re-definition of some black children. Those born of black-white alliances are no longer black as decreed by immutable law and social custom for centuries. They are now black-white, inter-racial, bi-racial, emphasizing the whiteness as the adoptable quality; a further subtle, but vicious design to further diminish black and accentuate white. We resent this high-handed arrogance and are insulted by this further assignment of chattel status to black people.... (National Association of Black Social Workers, 1974)

Thus, while an ideology of interracial adoptions was being promoted, there remained contention on the ethics and efficacy in regards at least to the intracountry adoption of black children. As a result, domestic interracial adoptions fell into disfavor (Lovelock, 2000), and a lack of the most "desired" adoptees_-white babies born in the US (Lovelock, 2000)—prompted prospective adoptive parents to continue pursuing international adoptions through the 1970's (Herman, 2012e). In this orphans continued to emigrate primarily from origin countries in Asia and Latin America (Lovelock, 2000)--often areas from which the US had a military presence (Lovelock, 2000).

It was also at this point that documentation of the problematic aspects of the institution of international adoption became more apparent. The majority of adoptions being processed at that time - and through the present day — were done not through non-profit adoption agencies, as one might expect, but through independent adoptions known as "proxy adoptions" (Lovelock, 2000). Proxy adoptions had been publicized as a means for international adoption since the 1950s 
(Herman, 2012c), though the inherent flaw within this method were evidently not advertised or otherwise acknowledged outside of the realm of adoption officials. Proxy adoptions allowed US citizens "to adopt in foreign courts by designating a proxy agent to act in their place" (Herman, 2012c). Proxy adoptions therefore allowed American parents to adopt without having to undergo American intracountry adoption requirements, such as social worker checks that a family met “minimum standards" (Herman, 2012b). The United States government — neither immigration nor any other agency_-interfered in Americans pursuing proxy adoptions, as it would have effectively meant interfering with the legalities of other sovereign nations (Herman, 2012c; Lovelock, 2000). Thus, international adoptees were not afforded the same legal protections as domestic adoptees, prompting criticisms by the US Children's Bureau, the Child Welfare League of America, and the American Branch of International Social Service of proxy advocates of developing a market of orphans under a guide of "humanitarian rhetoric" (Herman, 2012c). It appears that this might indeed have been the case. From 1966-1976, 60\% of the adoptees migrated from Asia (Lovelock, 2000), where at least one prominent adoption agency that pushed proxy adoptions (Holt International), has subsequently been revealed to have engaged in longterm falsification of records of the children they adopted out (Holt, n.d.b; Goudreau, 2014), as well as engaging in other insidious tactics that suggest extreme emotional and psychological pressure was placed on single birth mothers to place their children for adoption overseas (Heit, n.d.b). However, despite these criticisms it appears that a positive ideology of international adoption — and thus correspondingly usually international, interracial adoption — had already been socially constructed. This is evidenced by the fact that despite there being a number of (primarily non-white) adoptable children in the United States, adoptive parents continued to pursue adopting children overseas (Lovelock, 2000). Thus, if from the 1940s through the mid- 
1970s international adoption's first wave was characterized by "finding families for children", there emerged beginning the mid-1970s a second wave of "finding children for families" (Lovelock, 2000). It is therefore a distinct possibility that this ideology was a driving force in the commodification of children in the international adoption system, leading to such structural violence as instances of child trafficking. Lovelock phrases it succinctly:

Similar critiques and censure from representatives of relinquishing countries [similar to those intracountry adoption critiques] did not appear to have the same impact on intercountry interracial adoptions. The migratory aspect of this form of adoption undoubtedly protected the practice from critique, where common sense understandings of migration informed the evaluation of this practice. That is, the children from poorer nations (as with many migrants) were migrating for a 'better life'; their ethnicity or racial identity was a secondary concern. Ultimately, however, the issues surrounding ethnic identity and racial identification, which had raised concerns with domestic interracial adoptions, were not addressed for intercountry interracial adoptees, despite being equally pertinent. A double standard now existed where ethnic identity for child nationals available for adoption was an issue, but ethnic identity for children migrating for adoption was not. Further, these adoptions were now meeting a national need, and it appears that the needs and desires of prospective adoptive parents also shaped the emergent double standard. (Lovelock, 2000) 


\section{PART II - THEORETICAL UNDERPINNINGS}

\section{Galtung's Typology of Structural Violence}

I have so far posited that the ideology — the hegemony —of an adoption "saviordom" towards international adoptees, which has developed since the 1940s in the United States, is one of the driving forces leading to structural violence in international adoption. In utilizing this term, it is imperative to determine what exactly is meant in order to effectively make inferences on the institution of adoption.

Structural violence is a term originating the field of peace studies and conflict resolution, and its differentiating characteristic is that it is distinguishable from the concept of personal violence. Galtung originated this secernment in types of violence, and his terminological distinction of personal vs. structural violence have been widely adapted for use in other fields beyond peace studies, such as to analyze such unequal power structures as systemic male-female gendered violence (Price, 2012). For the purposes of this study, I will be utilizing Galtung's original typology. 


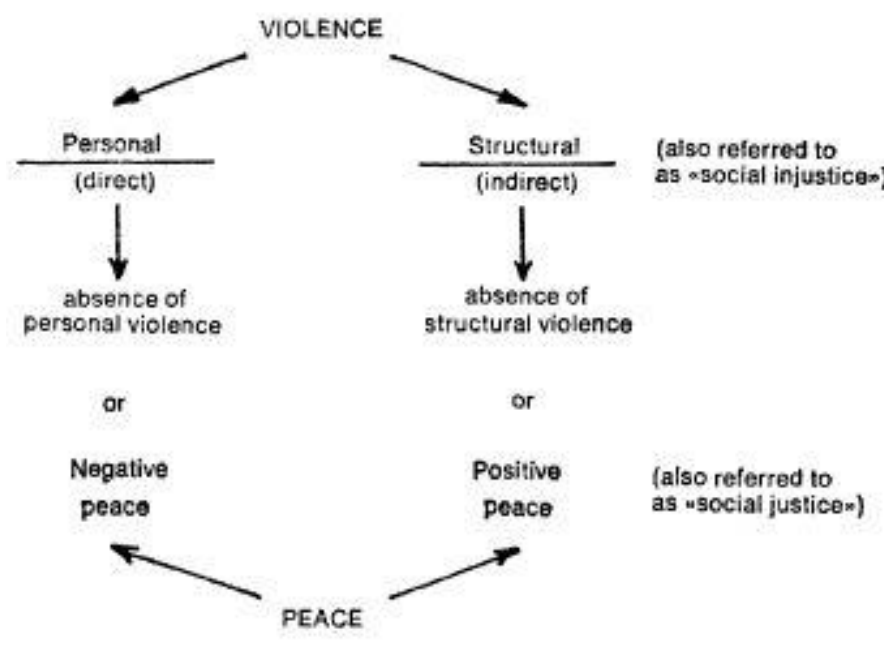

Illustration 1: Extended Concepts of Violence and

Peace (Galtung, 1969)

As illustrated in the image above, Galtung delineated a system of structural versus personal violence. Personal violence is the direct, somatic realization of violence. This is the form of personal force, whether physical or psychological, that is typically made visible. To use it in relation to this study, a possible form of personal violence in adoption could be an adoptive parent physically abusing or abandoning their adoptive child - this is the form that is so often recorded in the news media (Twohey, 2013). Structural violence on the other hand is the systemic, institutionalized form of violence, which benefits the party with the greater resources (e.g., those in a class-based society who hold the most privilege, or one nation state that holds dominion over another). An example of structural violence in adoption would be adoptive parents who possess the greater resources - money and housing, class, social perception of a supposedly superior family structure and other privileges - compared to families who, for lack of resources, are pressured to relinquish their children for adoption when they would otherwise choose to keep them. As charted in the image above, an absence of personal violence by itself 
leads only to what Galtung classified as a negative peace - there can remain structural violence within the system, even without the somatic realization of personal injury. Thus, children who are adopted by loving, supportive families can still be said to have been victims of a form of structural violence, given that the possibility of their remaining to be raised within their natal families and ethnic heritage was denied them due to social injustice. Conversely, where structural violence is absent there can exist positive peace - an adoption system absent the inequalities of social injustice could genuinely be described as a social institution that brings together children with families. Regrettably, however, social injustice - the harm caused by the "lack" that an adoptee and the adoptee's birth family suffers is a major driving force in the emigration of adoptees to the United States. This has resulted, as mentioned previously, in a hegemony of saving orphans from abroad, which has contributed to furthering an adoption market, leading to even more instances of structural violence, such as child trafficking. It is this glaring example of social imbalance within adoption to which I now turn. 


\title{
PART III - STRUCTURAL VIOLENCE IN INTERNATIONAL ADOPTION
}

\author{
Case Studies of Child Trafficking
}

Child trafficking for the purposes of international adoption is a documented phenomenon (Smolin, 2005; Dillon, 2003; Rafferty, 2010; Kapstein, 2003; Graff, 2008; Leifsen, 2008;

Wittern, 2003; Mullings, et. al, 2010; Getachew, 2012), with instances having occurred in myriad countries, including China, Ecuador, Brazil, Vietnam, India, Cambodia, Haiti, and Romania, among others). Though it is self-evident that most adoptive parents would never knowingly engage in child trafficking ${ }^{2}$, the ideology of saving an orphan via adoption nevertheless encourages child traffickers to find new "product" for the adoption marketplace (Smolin, 2005). This could partially be attributed to a misuse of the term orphan. As UNICEF states:

Unicef [sic] and global partners define an orphan as a child who has lost one or both birth parents. By this definition there were over 132 million orphans in sub-Saharan Africa, Asia, Latin America and the Caribbean in 2005. This large figure represents not only children who have lost both parents, but also those who

2 There is room for an argument here that there might be evidence for a form of personal violence perpetrated by American adoptive parents. At the very least, there appears to be a sort of cognitive dissonance at play here; there may be recognition that the demand from Western adoptive parents leads to corruption in the adoption system, and that continued adoptions disincentivizes reforms within the origin country to alleviate the social injustices that lead to families relinquishing their children in the first place. Yet, it appears that there is nevertheless a tenacious holding to the belief in the idea of a plethora of foreign orphans who need saving by Western parents. 
have lost a father but have a surviving mother or have lost their mother but have a surviving father.

Of the more than 132 million children classified as

orphans, only 13 million have lost both parents [italics added for

emphasis]. Evidence clearly shows that the vast majority of

orphans are living with a surviving parent[,] grandparent, or other

family member (“Orphans”, 2008).

In actuality then the idea that there exists a global orphan crisis (Kapstein, 2003; Graff, 2008) has been grossly overstated. Classifying a child who has a surviving parent as an "orphan" appears to be accepted when the context is that of an African, Asian, South American, or Eastern European nation. Paradoxically, classifying a child being raised by a single parent in the United States would clearly be ludicrous; there is no hegemony at present time of "saving" orphans of "single mothers" in the United States ${ }^{3}$, yet this hegemony persists if that mother (or father) lives in a developing nation. As UNICEF itself notes the "'orphan' statistic might be interpreted to mean that globally there are 132 million children in need of a new family, shelter, or care. This misunderstanding may then lead to responses that focus on providing care for individual children [e.g., via adoption] rather than supporting the families and communities that care for orphans and are in need of support" ("Orphans", 2008).

These responses have unfortunately generated a market commodifying children from developing nations, leading to separation from their birth families and communities of heritage.

3 This hegemony did exist in the early part of the $20^{\text {th }}$ century in the United States, when adoption agencies did not generally consider a family with a single parent as head of household as "normal" as a heteronormative married couple, though this has obviously changed with the emergence of new family structures in modern America. (Herman, 2012d) 
Smolin (2005) has termed this form of child trafficking as intercountry child laundering. This term "'child laundering' expresses the claim that the current intercountry adoption system frequently takes children illegally from birth parents, and then uses the official processes of the adoption and legal systems to 'launder' them as 'legally' adoptable' children. Thus, the adoption system treats children in a manner analogous to a criminal organization engaged in money laundering, which obtains funds illegally but then 'launders' them through a legitimate business. ...Child laundering needlessly and illicitly makes children in intact families into paper orphans, by using illegal means to separate them from their families" (Smolin, 2005). Two sample cases of this form of child trafficking for adoption are presented, and their forms of structural violence delineated below.

\section{Case 1: China}

China began allowing the migration of its children for overseas adoption in 1991 (Chang, 2003; Blair, 2005). The traditional preference for boy children (Chang, 2003) as well as rigorous enforcement of its "One Child Policy" had led to a case of abandoned infant girls being abandoned and then institutionalized; their numbers "overwhelmed Chinese orphanages... [where] underfunding and understaffing [sic] soon led to monstrous conditions" (Chang, 2003), pushing the orphanages beyond capacity (Blair, 2005). These conditions garnered critical international attention in the early 1990s, and China subsequently began "encouraging largescale international adoptions". However, suspect payments ${ }^{4}$ to the adoption orphanages triggered reactionary opinions of China promoting an "orphan market", as reported in the April

4 Payments in international adoption are not illegal, and are a generally accepted practice, provided that the monetary amount is "reasonable" and goes to the costs of raising the child, administrative fees for the adoption process, and/or are gifts to the orphanage or other institution which housed the child (Blair, 2005). 
11, 1993 Sunday magazine edition of The New York Times (Porter, 1993). China responded by temporarily stopping its intercountry adoption program, though soon resumed it afterward, "no doubt because the American demand for Chinese children was simply too great for the program to end permanently" (Chang, 2003). That Americans would choose to adopt from China in this instance is of course understandable; there was in this instance the appearance of genuine "need" for foreign families, as intracountry adoption within China was evidently not a popular option. It would thus seem reasonable that these unwanted baby girls would find homes with American adoptive parents who wanted children and had the means to take care of them. However, this belies the possibility that the birth parents may have wanted to keep their girls, and US adoptions decreased the incentivization for the Chinese government to revise their one-child policy to facilitate family unification. Then there is the possibility that the masses of abandoned baby girls in the past decade be more myth than fact. As reported in the

\section{Pulitzer Center on Crisis Reporting:}

This spring, the business magazine Caixin made headlines around the world when it uncovered corruption at Chinese adoption agencies involving children stolen from their families in Hunan Province and sold for steep prices in the international adoption arena. The news hit hard in the United States, which is home to about 60,000 children adopted from China, mostly girls.

For years, even social scientists have supported a widely held belief that Chinese orphanages are overrun with girls abandoned by their birth families. Two decades ago, when the gender ratio first started to skew sharply toward boys, many 
assumed these official figures were distorted by millions of unreported newborn girls. The country's strict one-child policy, they reasoned, prompted a widespread number of parents to conceal their additional children to avoid harsh penalties. Because of an enduring preference for boys, they surmised, many parents hid their girls or simply abandoned them.

In recent years, that theory has been increasingly challenged. "The more we look at the data, the more we realize the hidden children, they are not there," says Yong Cai, a sociologist at University of North Carolina at Chapel Hill. "They have never been born or they have simply been aborted." While some do conceal their children or abandon them, sex-selective abortion and poor health care for baby girls account for most of the sex ratio disparity for very young children, which now stands at about 120 males for every 100 females, Cai says. (Subramanian \& Lee, 2011)

In addition to this troubling reportage, there are also indications that where there was need for intracountry adoption, preference was heavily skewed to Western adoptive parents over potential domestic Chinese adopters. Whereas adoptive parents were required to be childless married couples over the age of 35, this requirement was not as strictly enforced for Westerners as it was for Chinese, severely restricting the possibility of domestic adoption (Blair, 2005). Moreover, adoptive Chinese parents who circumvented the regulations and informally adopted abandoned children would be penalized by family planning officials if discovered, effectively 
disincentivizing domestic adoption, as parents would be unable to obtain legal status for their adoptive children (which in China is "critical to obtain advanced educational and other governmental benefits for the children" [Blair, 2005]). As well, while the Chinese government was effective in fostering interest among international adopters, there was comparatively little effort in doing so for domestic adoption. ${ }^{5}$

Additionally, structural violence - the social injustice of uneven distribution of resources - is most evident in that while payments for adoption could be sometimes be equal for international and Chinese adopters, they were not equitable:

Scholars have expressed concern that the flow of funds created by international adoption, while being appropriately utilized to make significant improvements in the social welfare institutions and to provide developmental and educational programs for children who remain, might also draw the attention of orphanage officials away from the development of domestic adoption in their areas. Some orphanage officials, in fact, are reported to have set fees for domestic adoption at the same level as international adoption (U.S. $\$ 3,000$, or approximately 25,000 yuan), an amount that very few Chinese could afford. (Blair, 2005)

5 However, this began to change somewhat in the late 1990s, after approximately 30,000 children were adopted overseas. "In 1999, Chinese adoption law was revised to lower the age limit for adopting parents to thirty and to permit families with healthy children to adopt children from social welfare institutions. Though a critical reform, scholars have noted that publicity of the revisions has been local and sporadic, implementing regulations requiring written permission from family planning officials has deterred families with children from adopting in many areas, and those who adopted children outside of the institutions have had difficulty taking advantage of the new law. Nevertheless, adoption statistics for the year 2000 did signal a trend of increasing domestic adoption of both institutionalized children and noninstitutionalized [sic] children, which may in part be attributable to the 1999 reform" (Blair, 2005). 
According to the statistics provided by the U.S. Department of State, China remains a major sending country of adoptees to the United States, having sent 71,632 children from 19992013 (U.S. Department of State - Bureau of Consular Affairs, Office of Children's Issues, ca. 2014), which is approximately $29 \%$ of all international adoptions during that time frame. It seems likely then the hegemony of "rescuing" China's abandoned baby girls will continue, as will the structural violence inherent in the system between two countries.

\section{Case 2: Brazil}

International adoption from Brazil as a receiving country has been problematic, as this was a documented case of children being forcibly removed from their families for international adoption, against the express wishes of their biological parents (Cardarello, 2009). This violence occurred against the poorer class of the people in Itaguai, a municipality of Rio de Janeiro. Here, children were often living in a kinship system distinct from the nuclear family unit of upper-class Brazilians and Americans: a sort of fosterage system called familias de criaçāo.

It is not uncommon for children to circulate between different family milieus (the homes of grandmothers, other relatives, close friends, or neighbors), a practice that makes several adults responsible for the child's socialization. These children may speak of having two or more mothers, even when their biological mothers have maintained a relationship with them. Some of the Itaguai children laced for adoption by the judicial system had been living with grandparents or other extended family members, while others were living with familias de criação who were not biologically related to them. (Cardarello, 2009)

Legally, however, the children were considered abandoned and in the care of an "unauthorized third person" (Cardarello, 2009, p 7). Only the biological father and mother had 
the right to child custody, and the system of familias de criação is considered unfit. Thus, in court cases formal adoption is seen as the only way to guarantee a life of 'stability and dignity' for the child" (Cardarello, 2009). This perceptual mismatch between the law and the people of the familias de criaçāo has resulted in a heavy promotion of international adoption, as a means for profit for the middle and upper class in Brazil, and the adoption agencies who facilitate the emigration of the children overseas:

With the justification of helping poor children, local intermediaries such as attorneys, translators, and owners of adoption agencies, foster homes, and orphanages all profit from this enterprise. Under the pretext of expenses incurred in caring for the children, these intermediaries extract money from unsuspecting foreigners. In a context of more or less 'legal' or 'legitimate' practices, government bureaucrats and judicial agents may also be bribed to speed up the adoption procedure. The profits for individuals, the financial contributions from foreign agencies, and the 'donations' from the adoptive parents expected by the private institutions and NGOs in the country of origin all help [to] perpetuate a system of interest and reciprocity that encourages the increase in the supply of children for adoption by foreign families. (Cardarello, 2009)

Profit was not the only motivating factor; there is evidence of an ideology among upperclass Brazilians of "salvation", of rescuing a child from poverty and the supposed inevitability of criminality. This is representative of a general attitude among the upper echelon of many developing countries who associate poverty with criminality, and "the attitude that placing a 
child from a poor family in a wealthy family is naturally beneficial to the child" (Cardarello, 2009), irrespective of the birth parents' rights to raise their child(ren).

While in this instance of child trafficking the American influence in maintaining the structural violence is less insidious, it does speak to the fact there is complicity, as Americans continue to adopt from Brazil. As Cardarello notes, "One reason that a higher number of children from the Third World... are available for adoption is that the rights of their families of origin are not respected. In countries where the economic and cultural gap between the classes is less accentuated, such flagrant violations of the parents' rights do not occur" $(2009, \mathrm{p} 15)$. Thus, in deconstructing the implicit structural violence, it is safe to infer that receiving countries like the United States need to conscientiously consider the rights of families in developing nations, from their cultural context. 


\section{CONCLUSION}

A hegemony of adoption saviordom to fulfill American demand has led to corruption within the international adoption system, leading to such instances of structural violence as intercountry child laundering, separating children from their birth families and original communities. Protecting the interests of children and their families by attempting to address and alleviate the root causes leading to either relinquishment or illegal trafficking of children for adoption to the United States has not been considered a priority within the current ideology surrounding international adoption. It would therefore appear that further studies on the structural violence inherent in the intercountry adoption network is necessary to expand the popular discourse and consciously alter the ideology of "saving orphans" to that of "maintaining original families".

Implications for other future studies would also include an analysis those power dimensions inherent in international adoptions conducted via independent adoptions, which are in the majority, and those adoptions conducted via the intermediary of an adoption agency. Particularly the discursive practices of the agents facilitating independent adoptions (e.g., attorneys), and of adoption agencies—-both profit and non-profit—are in need of examination. Little formal research has been done in these areas, beyond Carter's ground-breaking dissertation of a multimodal critical discourse analysis of adoption agency websites (2011), wherein she found that there was evidence to suggest a marketing of children in a manner suggesting a discursive practice of commodification. Carter considered that this discourse constructed "children's bodies as a legitimate means of exchange", which served to support the social interests of the upper class at the expense of those marginalized groups from which the adoptees 
were born into. While that is the only instance of a formalized study of critical discourse analysis on the language surrounding adoption (domestic or international), there does exist ample "layman" critical discourse analysis available through social media conducted by adoptees themselves. An example of this is provided below, wherein Heit (2013), a self-identified Korean-American adult adoptee criticizes the language of Holt International's website "Holt Korea", an adoption agency which has been confirmed to engage in child trafficking (Goudreau, 2014; Holt, n.d.b): 


\section{Five Great Reasons to Adopt From Korea $\rightarrow$}

THE LANGUAGE IN THIS IS SO DISGUSTING - their attitude is clear, the business of selling children must go on!!

We know what you're thinking... The Korea program? Didn't Korea just pass a law slowing the adoption process? And doesn't Korea now require families to travel twice to complete their adoption?"

(The buying process just got harder for you because god forb id you should actually have to travel to adopt your child - so that they can get automatic US citizenship and avoid being deported like some adult adoptees today - instead of them being delivered to you in the past)

So give me one good reason why I should adopt from Korea?

(but here's why you should still give us your money)

1. Because children in Korea still need loving families to adopt them.

(actually, no. most of them don't. 90\% of the children sent for adoption today are the children of unwed mothers who essentially have no other "choice" but to give their children up for adoption. if there's no other choice, can we really call it a "choice"??? more here)

2. While the process has changed, the children have not! Although slightly older, children coming home to families are still toddler-age.

(the product is not as fresh, the toddlers might be a bit stale, but they still won't have gone rotten by the time you get them)

3. Like most other country programs, all children referred from Korea now have at least some health issues. But their conditions are often so minor that children are actually considered healthy in the U.S. Common conditions include prematurity, low birth weight or a minor heart murmur.

(we are manipulating the slightly lower health conditions of children into "children with disabilities" in order to send as many children for adoption as possible).... and finally....

The Korea program is still strong, and still moving... For 57 years, Holt has been uniting children from Korea with loving adoptive families in the U.S. Although rumors of end times in Korean adoption have ebbed and flowed over the years, children from Korea have continued to find homes overseas at a steady, uninterrupted pace - and we expect this legacy to continue for many years to come.

(if there's money to be made by manipulating western couples' desire to parent, unwed mothers' guilt and shame, and adoptees' birth records - we've done it for 57 years and can be damn sure we will find a way to continue to do it!)

(9) Jun 12, $201312: 14 \mathrm{pm}$. 60 Notes

Illustration 2: Screenshot of a critique of Holt's "Five Great Reasons to Adopt From Korea" (Heit, 2013) 
This and other examples of so-called layman critical discourse analysis are in themselves deserving of a meta-analysis within academia. As academic research is lagging in research behind that of what is available in such constantly evolving mediums as social media and other computer-mediated communication (Crystal, 2011), it is self-evident that more formal studies are needed, as they may be key to deconstructing the ideologies and their subsequently resultant forms of structural violence within the international adoption system. Until then, I posit that structural violence like child trafficking will continue to corrupt intercountry adoption. 


\section{REFERENCES}

Blair, M. (2005). Safeguarding the interests of children in intercountry adoption: Assessing the gatekeepers. Capital University Law Review, 34, 349-403.

http://digitalcommons.law.utulsa.edu/fac_pub/104/

Buck, P. (1972). I am the better woman for having my two black children. Today's Health, January, 21-22. http://darkwing.uoregon.edu/ adoption/archive/BuckIBW.htm

Cardarello, A. (2009). The movement of the mothers of the courthouse square: "Legal child trafficking," adoption and poverty in Brazil. The Journal of Latin American and Caribbean Anthropology, 14(1), 140-161. DOI: 10.1111/j.1935-4940.2009.01042.x

Carter, D. L. (2011). Multimodal critical discourse analysis of systematically distorted communication in intercountry adoption websites. (Unpublished doctoral dissertation). Washington State University. Retrieved from https://research.wsulibs.wsu.edu:8443/xmlui/bitstream/handle/2376/3502/Carter_wsu_0251E_10 296.pdf?sequence=1 (UMI No. 3495902)

Chang, I. (2003). The Chinese in America: A narrative history. NY: Viking Press.

Crystal, D. (2011). Internet linguistics: A student guide. New York: Routledge. 
Dillon, S. (2003). Making legal regimes for intercountry adoption reflect human rights principles: Transforming the United Nations Convention on the Rights of the Child with the Hague Convention on Intercountry Adoption. Boston University International Law Journal, 21, $179-257$.

Evans, A. (2014, July 25). "Orphans" and economics. Lost Daughters: Writing Adoption From a Place of Empowerment and Peace. Retrieved from http://www.thelostdaughters.com/2014/07/orphans-and-economics.html?m=1

Filipovic, J. (2013). The Evangelical Christian adoption movement: The orphan crisis that wasn't. Al Jazeera. Retrieved from http://www.aljazeera.com/indepth/opinion/2013/05/2013516308692198.html

Galtung, J. (1969). Violence, peace, and peace research. Journal of Peace Research, 6(3), 167191.

Getachew, I. (2012, December 14). In Ethiopia, placing institutions and adoption practices under scrutiny - and reuniting children with their families. UNICEF. Retrieved August 2, 2014, from http://www.unicef.org/infobycountry/ethiopia_66598.html

Goudreau, K. (2014). [Web log post]. Retrieved June 9, 2014 from http://holtproduct.wordpress.com/2014/05/01/while-adoptive-parents-are-buying-saving-orphans 
Graff, E. J. (2008, October 28). The lie we love. Foreign Policy. Retrieved from http://www.foreignpolicy.com/story/cms.php?story_id=4508\&print=1

Greenblatt, A. (2011, November 17). Fewer babies available for adoption by U.S. parents. NPR. Retrieved from http://www.npr.org/2011/11/17/142344354/fewer-babies-available-foradoption-by-u-s-parents

Heit, S. (2013, June 12). 5 great reasons to adopt from Korea [Web log post]. Retrieved May 11, 2014, from http://peaceshannon.tumblr.com/post/52762073706/five-great-reasons-to-adoptfrom-korea

Heit, S. (n.d.). [Web log post]. Retrieved May 11, 2014, from http://peaceshannon.tumblr.com/tagged/adoption

Heit, S. (n.d.) [Web log post]. Retrieved July 20, 2014, from http://peaceshannon.tumblr.com/tagged/holt

Herman, E. (2012, February 24). Matching. The Adoption History Project. [University of Oregon Department of History]. Retrieved July 15, 2014, from http://darkwing.uoregon.edu/ adoption/topics/matching.html Herman, E. (2012, February 24). Minimum standards. The Adoption History Project. [University of Oregon Department of History]. Retrieved July 15, 2014, from 
http://darkwing.uoregon.edu/ adoption/topics/minimumstandards.htm

Herman, E. (2012, February 24). Proxy adoptions. The Adoption History Project. [University of Oregon Department of History]. Retrieved July 15, 2014, from http://darkwing.uoregon.edu/ adoption/topics/proxy.htm

Herman, E. (2012, February 24). Single parent adoptions. The Adoption History Project. [University of Oregon Department of History]. Retrieved September 13, 2014, from http://pages.uoregon.edu/adoption/topics/singleparentadoptions.htm

Herman, E. (2012, February 24). Transracial adoptions. The Adoption History Project. [University of Oregon Department of History]. Retrieved July 15, 2014, from http://darkwing.uoregon.edu/ adoption/topics/transracialadoption.htm

Hübinette, T. (2005). Comforting an orphaned nation: Representations of international adoption and adopted Koreans in Korean popular culture. (Doctoral dissertation). Stockholm University. Retrieved from http://su.diva-portal.org/smash/get/diva2:197367/FULLTEXT01.pdf

Kapstein, E.B. (2003). The baby trade. Foreign Affairs, 82(6), 115-125. http://www.jstor.org/stable/20033761

Kennedy, R. (1994). Orphans of separatism: The painful politics of transracial adoption. American Prospect, 17, 40-42. Retrieved from 
http://darkwing.uoregon.edu/ adoption/archive/KennedyOOS.htm

Leifsen, E. (2008). Child trafficking and formalisation: The case of international adoption from Ecuador. Children \& Society, 22, 212-222. DOI: 10.1111/j.1099-0860.2008.00152.x

Lovelock, K. (2000). Intercountry adoption as a migratory practice: A comparative analysis of intercountry adoption and immigration policy and practice in the United States, Canada and New Zealand in the post W.W. II period. International Migration Review, 34(4), 907-949. http://www.jstor.org/stable/2675949

Mullings, B.; Werner, M.; \& Peake, L. (2010). Fear and loathing in Haiti: Race and politics of humanitarian dispossession. ACME: An International E-Journal for Critical Geographies, 9(3), 282-300.

National Association of Black Social Workers. (1974). Position Statement on Trans-Racial Adoption, September, 1972. In R.H. Bremner (Ed.), Children and youth in America: A documentary history (Vol. 3, Parts 1-4) 777-780. Boston: Harvard University Press. [Reproduced excerpt retrieved from] http://darkwing.uoregon.edu/ adoption/archive/NabswTRA.htm

Orphans. (2008, August 21). Retrieved May 21, 2014, from http://www.unicef.org/media/media_45279.html 
Porter, B. (1993, April 11). China's market in orphan girls: China's newest export. The New York Times.

Price, J. (2012). Structural violence [Kindle version]. Retrieved from amazon.com

Rafferty, Y. (2007). Children for sale: Child trafficking in Southeast Asia. Child Abuse Review, 16, 401-422. DOI: 10.1002/car.1009

Roberts, D. (2013, December). "I see hope in connections" - An interview with Dorothy Roberts, Part II [Interview by S. Gibney]. Gazillion Voices: Land of a Gazillion Adoptees Magazine. Retrieved from http://gazillionvoices.com/i-see-hope-in-connections-an-interview-with-dorothyroberts-part-ii/\#.VGPpojTF-Sp

Smolin, D. (2005). Child laundering: How the intercountry adoption system legitimizes and incentivizes the practices of buying, trafficking, kidnapping, and stealing children. The Wayne Law Review, 52, 113-200. http://law.bepress.com/expresso/eps/749

Stanley, K. (2013, December 9). Thinking of adopting? [Web log post]. Sister Wish: Open Adoption Adoptee Blog. Retrieved July 31, 2014, from http://www.sisterwish.com/thinking-ofadopting/

Subramanian, S. \& Lee, D.J. (2011, October 19). China: Black market babies. Pulitzer Center on Crisis Reporting. Retrieved from http://pulitzercenter.org/reporting/china-children-stolen- 
sold-orphanage-adoption

Twohey, M. (2013, September 9). The child exchange: Inside America's underground market for adopted children. Reuters. Retrieved from http://www.reuters.com/investigates/adoption/

United States, U.S. Department of State - Bureau of Consular Affairs, Office of Children's Issues. [ca. 2014]. Statistics. Retrieved August 1, 2014, from http://adoption.state.gov/about_us/statistics.php

Van Dijk, T. (1998). Ideology: A multidisciplinary approach. London: SAGE.

Voigt, K. (2013, September 18). International adoption: Saving orphans or child trafficking? CNN. Retrieved from http://www.cnn.com/2013/09/16/world/international-adoption-savingorphans-child-trafficking/

Voigt, K. \& Brown, S. (2013, September 17). International adoptions in decline as number of orphans grows. CNN. Retrieved from http://www.cnn.com/2013/09/16/world/internationaladoption-main-story-decline/

Virgiel, V. (2014). International adoption and the white-savior industrial complex: A discourse analysis. [unpublished essay].

Vu, M.A. (2010, July 20). Adoption agency: Major increase in U.S. interest in orphans. The 
Christian Post. Retrieved July 14, 2014 from http://www.christianpost.com/news/adoptionagency/major-increase-in-us-interest-in-orphans-45980

Winfrey, O. [n.d.]. Oprah where are they now: Liberian orphans sing the praises of their adoptive American family. [Video file]. Retrieved from http://www.oprah.com/own-where-arethey-now/Liberian-Orphans-Sing-the-Praises-of-Their-Adoptive-Family-Video.

Wittner, K.M. (2003). Curbing child-trafficking in intercountry adoptions: Will international treaties and adoption moratoriums accomplish the job in Cambodia? Pacific Rim Law \& Policy Journal, 12(2), 595-629. http://digital.law.washington.edu/dspacelaw/bitstream/handle/1773.1/735/12PacRimLPolyJ595.pdf?sequence=1 